AN L- 7106

Reactor Technology (TID-4500, 45th Ed.) AEC Research: and Development Report

\author{
ARGONNE NATIONAL LABORATORY \\ 9700 South Cass Avenue \\ Argonne, Illinois 60440
}

FARET CORE I FUEL IRRADIATION PROGRAM AND REFERENCE DESIGN

\author{
by \\ P. J. Persiani \\ Reactor Physics Division \\ T. R. Bump and W. J. Kann \\ Reactor Engineering Division
}

October 1965

\footnotetext{
Operated by The University of Chicago under

Contract W-31-109-eng-38 with the

U. S. Atomic Energy Commission
} 


\section{DISCLAIMER}

This report was prepared as an account of work sponsored by an agency of the United States Government. Neither the United States Government nor any agency Thereof, nor any of their employees, makes any warranty, express or implied, or assumes any legal liability or responsibility for the accuracy, completeness, or usefulness of any information, apparatus, product, or process disclosed, or represents that its use would not infringe privately owned rights. Reference herein to any specific commercial product, process, or service by trade name, trademark, manufacturer, or otherwise does not necessarily constitute or imply its endorsement, recommendation, or favoring by the United States Government or any agency thereof. The views and opinions of authors expressed herein do not necessarily state or reflect those of the United States Government or any agency thereof. 


\section{DISCLAIMER}

Portions of this document may be illegible in electronic image products. Images are produced from the best available original document. 
. $\underline{\ddot{P} \text { age }}$

I. INTRODUCTION .................. 4

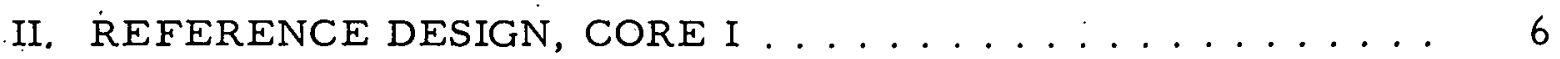

A. Basic Core Plan. . . . . . . . . . . . . . 6

B. Thermal Considerations . . . . . . . . . . 8

C. Instrumented Fuel Subassemblies and Fuel-element Design. 9

D. Core Composition and Configuration.............. 9

E. Considerations in Planning the Experimental Program .... 13

F. FARET Critical Experiments............... 15

1. Control-rod Experimental Results ........... 15

2. Establishing Concept of Mixed Core Systems . . . . . . 15

G. The Experimental Program . . . . . . . . . . . 16

ACKNOW LEDGMENTS . . . . . . . . . . . . . . . . . . . 21

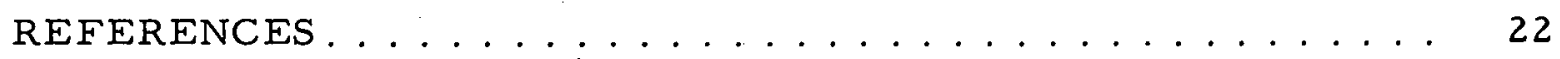




\section{LIST OF FIGURES}

No.

Title

Page

1. Instrumented Core Subassembly ................. 10

2. FARET Core I Experiment. ................. 11

3. Relative Radial Power Density Distribution at Core I Center

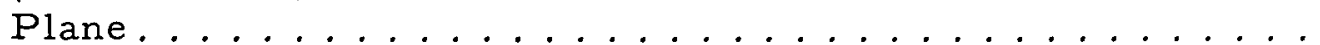

4. PerCent Heavy Atom. Burnup versus Full-power Operating

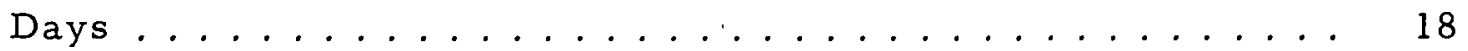

5. Variation of Reactivity versus Fuel-irradiation Periods (Days)

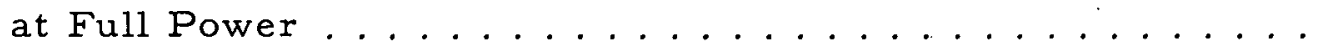

\section{LIST OF TAB LES}

No.

Title

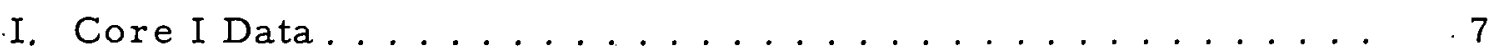

II. Fuel-element Data .................... 7

III. Subassembly Data. . . . . . . . . . . . . . 7

IV. Assumptions for Thermal Calculations. . . . . . . . . 8

V. Performance Parameters of FARET Core I . . . . . . . . . 12

VI. Calculated Nuclear and Control Parameters for FARET

Core I Reference Design. . . . . . . . . . . . . . . 14

VII. Control-rod for FARET Critical Experiments on Oxide Loading ........................... 15

VIII. Subassembly Replacements in the FARET Critical

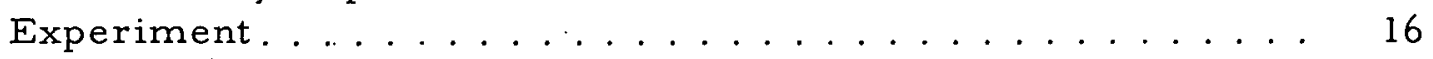

IX. Experimental Program Removal and Replacement Sequence. . 17 


\title{
FARET CORE I FUEL IRRADIATION PROGRAM \\ AND REFERENCE DESIGN
}

\author{
by \\ P. J. Persiani, T. R. Bump \\ and W. J. Kann
}

\section{INTRODUCTION}

The primary objective of the first experiment in the Fast Reactor Test Facility (FARET) $)^{1}$ is the testing and verification of fast-reactor fuel elements typical of those likely to be used in the large, fast, prototype power reactor which is part of the AEC's fast reactor development program.

Since the core and fuel specifications must be developed for FARET prior to the design of the prototype reactor, the FARET Core I design and operating conditions are being planned so that they can bracket the corresponding design specifications of the power reactor. Core I will test several different fuel-element designs under instrumented conditions, in order to provide the maximum of information which can be used to evaluate, define, or verify operating limits for the first core of the prototype reactor.

FARET Core I contains oxide, carbide, and metal fuel subassemblies driving each other. The several different designs of oxide, carbide, and metal reflect current judgment on the most likely operating conditions for the prototype. Specific design choices as to clad material, fuel density, clad temperatures, etc., have been made for the reference core. The research and development program for FARET Core I will test and evaluate these design choices, as well as some alternate design possibilities, prior to final specification of the core.

It is planned to study the performance of oxide, carbide, and metal fuel subassemblies simultaneously in a small, 70-liter core with a powerdensity distribution that will allow up to $15 \%$ heavy atom burnup in about 3 years of operation. With the small core, the design and the geometry of the prototype reactor can be simulated, but the fuel enrichment will be different. The $\mathrm{Pu}^{239}$. content is made similar to that of the large reactor by the replacement of $U^{238}$ with $U^{235}$ to achieve criticality. ${ }^{2}$ Therefore, by selection of reactor position and/or enrichment in $U^{235}$, performance ratings will be achieved that bracket the anticipated operating conditions appropriate to the prototype power reactor. 
The basis for utilizing this enrichment technique is that the substitution of $\mathrm{U}^{235}$ for $\mathrm{U}^{238}$ would not alter the metallurgical or physical properties of the fuels, at.least to a first-order approximation. The $\mathrm{U}^{235}$-enriched, uranium-plutonium system is chemically similar to a nonenriched, uraniumplutonium system.

This technique is compared with the method in which a nonenriched, uranium-plutonium system is irradiated in a higher-neutron-flux environment to achieve the same rate of heavy atom burnup. The fission-reaction rate, which is related to the index of fuel performance (burnup of heavy atoms) is the parameter common to both techniques. In one method, a given product of the neutron flux and macroscopic fission cross section is achieved by varying the atomic density of the fissile material; the other method requires the production of an external source of a higher neutron flux.

Phenomena such as diffusion, or plutonium segregation, which depend on force fields arising. from temperature gradients, are expected to differ, if at all, only to second order. The reasons for this are as follows: First, for a given fission-reaction rate, the fission distribution, and hence the heat generation (and temperature gradient), in a fuel element should be the same for both systems. This is the case in a fast neutron environment since the fast flux would have a flat distribution in a small-diameter (0.5- to $1.0-\mathrm{cm}$ ) fuel pin. Second, in the case of the diffusion of atoms, a difference in the diffusion coefficient would imply an isotopic mass dependence. ${ }^{3}$ Because of the heavy masses involved, the diffusion coefficient and the resulting forcing function for the two mixed fuels is expected to differ only in second order.

The dimensional stability of a fuel pin and the design of the cladding to withstand internal gas pressures are dependent on the generation of gas eous fission products. A study of the fission yields from $\mathrm{U}^{235}$ and $\mathrm{Pu}^{239}$ for thermal neutrons ${ }^{4}$ and of estimates for fast neutrons ${ }^{5}$ indicates that the total yicld of the more prevalent gaseous fission products (krypton, xenon, iodine, and cesium) are similar to within $10 \%$. When the yields for a mixed, $\mathrm{U}^{235}$ enriched, uranium-plutonium fuel are compared with a nonenriched, uraniumplutonium mixture, the difference becomes much.less than $10 \%$. For a total uranium-to-plutonium atom ratio of about 5/1, a 50 to $60 \% \mathrm{U}^{235}$ enrichment, and approximating a $\mathrm{U}^{235}-$ to $-\mathrm{Pu}^{239}$ fissioning ratio of $1 / 2$, the difference in the yields would be about $6 \%$.

A difference in the fission-gas release rates and fission-product migration might exist if a fuel is used in which the plutonium is not in solid solution with the uranium. The existence and the extent of these differences have not yet been established. Even if these differences are observed, the effect is expected to become minimal at the high operating fuel temperatures of FARET and larger power reactors. 
Therefore, the performance ratings of fuel-element designs, obtained by using the enrichment technique as in FARET, can be assigned to prototype reactor elements with a good degree of confidence.

If it becomes necessary to establish this correlation to a higherorder approximation, one or more control subassemblies can be readily included at any stage of the experimental program.

The advantage of the above technique is that many different fuelelement designs may be tested simultaneously in a flexible and accessible small-core loading.

The hard neutron spectrum and the magnitude of the flux in FARET would subject the clad material to neutron dose rates comparable to those that would be obtained in the typical softer spectrum of a large, fast, power reactor at the same fuel ratings. The frequency of adding or replacing fuel elements in order to maintain.criticality is determined only by the experimental requirements of these same test elements. The fuel inventory is determined only by the number of test assemblies required in the experiment. The flexibility in core size allows the generation of experimental data at accelerated rates of heavy atom burnup. Along with these low fuel loadings is the advantage of needing only a low heat 'removal system.

The FARET Core I reference design assumes that as the subassemblies are removed for inspection and destructive testing, they will be replaced with fresh subassemblies of the same design. This need not be the case. Improved fuel-element designs resulting from the continuing fastreactor fuels-development program can be inserted into the core whenever available, replacing types showing a reduced performance capability. Further, should some originally fabricated designs prove to be of less interest in the early stages of the FARET experiment, they would be replaced by additional subassemblies of other designs having greater potential. Extra subassemblies of several types will be provided in the original fuel inventory. The physics of the core permits such flexibility.

\section{REFERENCE DESIGN, CORE I}

\section{A. Basic Core Plan}

The FARET Core I reference deșign will consist of carbide, metal, and oxide fuels and will test simultaneously ten different fuel-element designs with good statistics. The Core I data are presented in Table I. Two of the oxide designs will be run at two different linear heat-power ratings, and hence different maximum cladding temperature. The fuel-element types and designs and the tentative conditions are presented in Tables II and.III. The elements are typed according to fuel material, fabrication method, clad material, and/or thermal conditions. 
TABLE I. Core I Data

\begin{tabular}{|c|c|c|c|}
\hline \multicolumn{2}{|l|}{ Entire core } & \multicolumn{2}{|l|}{ Radial reflector } \\
\hline Equivalent diameter, in. & 17.5 & $\overline{\text { Height, in. }}$ & 80 \\
\hline Height, in. & 18 & Equivalent outside diameter, in. & 42.3 \\
\hline Volume, liters & 70 & Radial thickness, in. & 13.1 \\
\hline Subassemblies & & Radial reflector composition, $\mathrm{v} / \mathrm{o}$ & \\
\hline Mixed oxide & 24 & Stainless steel & 82 \\
\hline Mixed carbide & 16 & Sodium & 18 \\
\hline $\mathrm{Pu}, \mathrm{U}$ alloy & 8 & Heat output, MW & 50 \\
\hline Special subassemblies & 3 & $\frac{\text { Heat output, } \mathrm{N} w}{\text { Primary sodium temperature, }{ }^{\circ} \mathrm{F}}$ & 50 \\
\hline Control rods & 12 & Tocore & 810 \\
\hline $\begin{array}{l}\text { Radial reflector (including loops) } \\
\text { Total }\end{array}$ & $\begin{array}{l}238 \\
301\end{array}$ & From core (nominal) & 1050 \\
\hline Configuration & Hexagonal & Primary sodium flow rate & \\
\hline Dimension across flats, in. & 2.290 & Through core, gal $/ \mathrm{min}$ & 6000 \\
\hline Lattice spacing, in. & 2.320 & Core pressure drop, psi & 80 \\
\hline Tube-wall thickness, in. & 0.040 & & \\
\hline Control-rod composition, $v / o$ & & & \\
\hline Boron carbide & 55 & & \\
\hline Stainless steel & 20 & & \\
\hline Sodium & 25 & & \\
\hline
\end{tabular}

TABLE II. Fuel-element Data

\begin{tabular}{lccc}
\hline \multicolumn{1}{c}{ Fuel Material } & $\mathrm{UO}_{2}-15 \mathrm{w} / \mathrm{OPuO} \mathrm{P}_{2}$ & $\mathrm{UC}-15 \mathrm{w} / \mathrm{O} \mathrm{PuC}$ & $\mathrm{Metal}^{\mathrm{b}}$ \\
\hline Elements per subassembly & 37 & 37 & 61 \\
Fuel height, in. & 18 & 18 & 18 \\
Clad outside diam, in. & 0.290 & 0.290 & 0.220 \\
Clad thickness, in. & 0.020 & $0.020^{\mathrm{a}}$ & 0.016 \\
Spacer wire diam, in. & 0.057 & 0.057 & 0.052 \\
Axial blanket height (each end), in. & 6 & 6 & 6 \\
Gas reservoir, in. & 25 & 25 & 25 \\
Element height, in. & 55 & 55 & 55 \\
Effective fuel density, $\%$ & 80 & 80 & 70 \\
Bond material & Helium & Helium & Sodium \\
Fuel U/Pu atom ratio & $6 / 1$ & $6 / 1$ & $5 / 1$ \\
Fuel details & Coprecipitated; & Single Phase; & - \\
& O/M 1.97-2.00 & Solid Solution & \\
\hline
\end{tabular}

a 0.015 in $\mathrm{C} 4$ subassemblies.

$\mathrm{b}_{U-15} \mathrm{w} / 0 \mathrm{Pu}-6.5 \mathrm{w} / 0 \mathrm{Ti} ; \mathrm{U}-15 \mathrm{w} / 0 \mathrm{Pu}-10 \mathrm{w} / 0 \mathrm{Zr}$.

TABLF III. Subassembly Data

\begin{tabular}{|c|c|c|c|c|c|c|c|c|c|c|c|}
\hline $\begin{array}{c}\text { Fuel } \\
\text { Material }\end{array}$ & $\begin{array}{l}\text { Subassembly } \\
\text { Designation }\end{array}$ & $\begin{array}{l}\text { Fuel } \\
\text { Type }\end{array}$ & $\begin{array}{c}\text { Clad } \\
\text { Material }\end{array}$ & $\begin{array}{c}\text { No. of } \\
\text { Subassemblies }\end{array}$ & $\begin{array}{l}\text { Instrumented } \\
\text { Subassembly }\end{array}$ & $\begin{array}{l}\text { Maximum } \\
\text { Linear } \\
\text { Heat Flux } \\
\text { (Design), } \\
\text { kW/ft }\end{array}$ & $\begin{array}{l}\text { Maximum } \\
\text { Clad Temp. } \\
{ }^{\circ}\left({ }^{\circ} \mathrm{C}\right)\end{array}$ & $\begin{array}{l}\text { Maximum } \\
\text { Fuel Temp, } \\
{ }^{\circ}\left(^{\circ} \mathrm{C}\right)\end{array}$ & $\begin{array}{c}\text { Burnups } \\
\text { at Removal, } \\
\text { a/o }\end{array}$ & $\begin{array}{l}\text { Maximum } \\
\text { Clad Thermal } \\
\text { Stress, psi }\end{array}$ & $\begin{array}{c}\text { Coolant } \\
\text { Velocity, } \\
\text { ft/sec }\end{array}$ \\
\hline Oxide & $\begin{array}{l}01 \\
02 \\
03 \\
04 \\
05 \\
06\end{array}$ & $\begin{array}{l}\text { Pellets } \\
\text { Pellets } \\
\text { Vipak } \\
\text { Vipak } \\
\text { Pellets } \\
\text { Vipak }\end{array}$ & $\begin{array}{l}304 \\
304 \\
304 \\
304 \\
\text { HSA } \\
\text { HSA }\end{array}$ & $\begin{array}{l}4 \\
4 \\
4 \\
4 \\
4 \\
4\end{array}$ & $\begin{array}{l}\text { (1) } \\
\text { (1) } \\
\text { (1) } \\
\text { (1) } \\
\text { (1) } \\
\text { (1) }\end{array}$ & $\begin{array}{l}15 \\
22 \\
15 \\
22 \\
22 \\
22\end{array}$ & $\begin{array}{l}1250(675) \\
1290(700) \\
1250(675) \\
1290(700) \\
1340(725) \\
1340(725)\end{array}$ & $\begin{array}{l}3220(1770) \\
4220(2330) \\
3220(1770) \\
4220(2330) \\
4250(2340) \\
4250(2340)\end{array}$ & $\begin{array}{l}5,9,12,14 \\
5,8,10,12 \\
5,9,12,14 \\
5,8,10,12 \\
5,9,12,15 \\
5,9,12,15\end{array}$ & $\begin{array}{c}13,300 \\
19,400 \\
13,300 \\
19,400 \\
- \\
-\end{array}$ & $\begin{array}{l}16 \\
23 \\
16 \\
23 \\
20 \\
20\end{array}$ \\
\hline Carbide & $\begin{array}{l}\mathrm{Cl} \\
\mathrm{C} 2 \\
\mathrm{C} 3 \\
\mathrm{CA}\end{array}$ & $\begin{array}{l}\text { Pellets } \\
\text { Vipak } \\
\text { Pellets } \\
\text { Vipak }\end{array}$ & $\begin{array}{l}304 \\
304 \\
\text { HSA } \\
\text { HSA }\end{array}$ & $\begin{array}{l}4 \\
4 \\
4 \\
4\end{array}$ & $\begin{array}{l}\text { (1) } \\
\text { (1) } \\
\text { (1) } \\
\text { (1) }\end{array}$ & $\begin{array}{l}15 \\
22 \\
29 \\
36\end{array}$ & $\begin{array}{l}1250(675) \\
1290(700) \\
1340(725) \\
1340(725)\end{array}$ & $\begin{array}{l}2030(1110) \\
2520(1380) \\
3050(1680) \\
3390(1870)\end{array}$ & $\begin{array}{l}5,9,12,14 \\
5,9,12,14 \\
5,9,12,15 \\
5,9,12,15\end{array}$ & $\begin{array}{c}13,300 \\
19,400 \\
- \\
-\end{array}$ & $\begin{array}{l}16 \\
23 \\
30 \\
39\end{array}$ \\
\hline Metal & $\begin{array}{l}M 1 \\
M 2\end{array}$ & $\begin{array}{l}U-P u-Z r \\
U-P U-T i\end{array}$ & $\begin{array}{l}\mathrm{HSA} \\
\mathrm{V}-\mathrm{Ti}\end{array}$ & $\begin{array}{l}4 \\
4\end{array}$ & (1) & $\begin{array}{l}14 \\
14\end{array}$ & $\begin{array}{l}1250(675) \\
1250(675)\end{array}$ & $\begin{array}{l}1580(860) \\
1580(860)\end{array}$ & $\begin{array}{l}5,9,12,14 \\
5,9,12,14\end{array}$ & $\begin{array}{l}- \\
-\end{array}$ & $\begin{array}{l}20 \\
20\end{array}$ \\
\hline \multirow[t]{2}{*}{ Advanced } & CAS & - & - & 3 & (3) & & & & & & \\
\hline & & & & 51 & (15) & & & & & & \\
\hline
\end{tabular}

NOTES: 1. Vipak means "vibratory compacted;" HSA means "high-strength alloy," not necessarily the same for oxide as for carbide, etc.

2. Coolant inlet temperature is $810^{\circ} \mathrm{F}$. Average outlet temperature from each subassembly is $1050^{\circ} \mathrm{F}$. (Exception: outlet temperature from 05 and O6 subassemblies is 1085 .) Axial peaking factor -1.2 .

3. Maximum clad temperature include both a 1.33 factor for flow and power maldistribution effects on coolant temperature rise, and a 1.10 uncertainty factor. Maximum fuel temperatures include the 1.33 factor but no uncertainty factor.

-Approximate burnup intervals. 
The reference core contains six mixed-oxide types, for a total of 24 oxide subassemblies; four mixed-carbide types, for a total of 16 carbide subassemblies; two metal alloy types for a total of eight subassemblies; and three subassemblies for special experiments, making an overall total of 51 (see Table III). Two loops at the core edge and one loop in the reflector are also planned; details of the experimental program in the loops and the special subassemblies will be provided later.

Each subassembly type is to be tested up to about 15 heavy a/o burnup, if the design permits. The elements are to be destructively tested at predetermined subintervals of burnup. The suggested periods reflect the current confidence of the metallurgists that most of these elements can achieve at least the first two burnup periods. Also reflected in the frequency of inspection is the attempt to maximize reactor full-power operating time. As will be subsequently discussed, other important constraints on the frequency of testing and irradiation intervals are the maintaining of criticality and the worth of the control system.

\section{B. Thermal Considerations}

An average coolant outlet temperature from each subassembly of $1050^{\circ} \mathrm{F}$ has been chosen because it is believed that reactor plant temperature of that order will be of interest for some years to come, due to overall economic considerations. In those subassemblies in which the high 1.33 factor applied to the average coolant-temperature rise proves to be too large, the average outlet temperature will be raised to produce the maximum clad temperatures given in Table III.

With regard to the maximum fuel temperatures, uncertainty factors are not included in the fuel temperatures given in Table III. It is believed that a factor of not more than 1.3 will eventually prove to be appropriate. (This uncertainty factor is applied to the difference between the maximum fuel temperature and the coolant inlet temperature.) If the factor is 1.3 , however, the maximum oxide temperature becomes $2910^{\circ} \mathrm{C}$ and the maximum metal temperature becomes $990^{\circ} \mathrm{C}$. Such temperatures appear to be high. If the uncertainty factor proves to be as high as 1.3 , the power in some of the oxide and metal fuel elements may have to be reduced. In that event, the coolant outlet temperatures can be increased to keep the maximum clad temperatures as high as those in Table III. Table IV lists the assumptions used in the thermal calculations.

\begin{tabular}{|c|c|c|c|c|}
\hline $\begin{array}{c}\text { Fuel } \\
\text { Material }\end{array}$ & $\begin{array}{c}\text { Sodium Film } \\
\text { Coefficient, } \\
\text { Btu } \mathrm{hr}^{-1} \mathrm{ft}^{-2}{ }^{\circ} \mathrm{or}^{-1}\end{array}$ & $\begin{array}{l}\text { Clad Thermal } \\
\text { Conductivity, } \\
\text { Btu } \mathrm{hr}^{-1} \mathrm{ft}^{-1} \circ \mathrm{F}-1\end{array}$ & $\begin{array}{l}\text { Fuel-clad Interface } \\
\text { Conductance, } \\
\text { Btu } \mathrm{hr}^{-1} \mathrm{ft}^{-2}{ }^{\circ} \mathrm{F}-1\end{array}$ & $\begin{array}{l}\text { Fuel Thermal } \\
\text { Conductivity, } \\
\text { Btu } \mathrm{hr}^{-1} \mathrm{ft}^{-1} \mathrm{oF}_{\mathrm{F}}-1\end{array}$ \\
\hline $\begin{array}{l}\text { Oxide } \\
\text { Carbide } \\
\text { Metal }\end{array}$ & $\begin{array}{l}20,000 \\
20,000 \\
20,000\end{array}$ & $\begin{array}{l}13.5 \\
13.5 \\
14.5 \\
\end{array}$ & $\begin{array}{l}1,500 \\
1,500 \\
40,000^{b}\end{array}$ & $\begin{array}{c}1.7^{a} \\
10^{b}\end{array}$ \\
\hline \multicolumn{5}{|c|}{$\begin{array}{l}\text { athe fuel is assumed to have a central hole large enough to produce an "effective" fuel density of } 85 \pi, \text { provided that the } \\
\text { remainder of the jacket interior is filled with fuel of } 100 \% \text { density. This condition reduces the temperature rise through } \\
\text { the fuel to } 67 \% \text { of that through a solid fuel pellet. The central hole is expected to form in oxide at centerline tempera- } \\
\text { tures above } 1600-1800^{\circ} \mathrm{C} \text {. } \\
\text { bThe fuel is considered to have expanded against the jacket, displacing the bond sodium, and to have an accompanying } \\
\text { reduction in thermal conductivity. }\end{array}$} \\
\hline
\end{tabular}


C. Instrumented Fuel Subassemblies and Fuel-element Design

The design of the reference core subassembly selected for FARET employs the EBR-II hexagonal shape. The core is constructed using a close packed geometry (for dimensions see Table I) of 301 total subassemblies. There are 51 fuel elements and 12 control rods, the remaining locations being occupied by the loop and the stainless-steel reflectors. A conceptual instrumented fuel subassembly is illustrated in Fig. 1 .

The design of the fuel-element fission-gas reservoir assumed an estimated fission-gas generation of 2.4 and $2.9 \mathrm{cc} /(\mathrm{cc}$ of fuel) (a/o burnup) for the oxide and carbide fuels, respectively. It was further assumed that a $10.0 \%$ fission-gas release could occur in the oxide fuel and that a $.75 \%$ fission-gas release would occur in the carbide fuel. The highest clad stress, and hence the most pessimistic case, occurs in the oxide fuel elements with $14 \%$ burnup, $304 \mathrm{SS}$ clad, and a maximum clad temperature of $675^{\circ} \mathrm{C}$. The maximum temperature of the gas reservoir is $610^{\circ} \mathrm{C}$. Under these conditions, the pressure stress in the cladding is about 6000 psi. Recent data indicate that a stress of 8000 psi will produce $1 \%$ creep in $10,000 \mathrm{hr}$ in Type 304 stainless steel at $675^{\circ} \mathrm{C}$. Therefore, from the point of view of cladding stress, it appears that the burnup goals listed in Table III can be realizable in FARET.

The approach adopted in the design of the fuel elements is toward a thick-wall cladding. This is better able to withstand fission-gas and fuelswelling pressures than a thin-wall cladding. The thick-wall cladding will be subjected to higher thermal stresses than thin-wall cladding, but Case 1331 of the Nuclear Vessels Code indicates that many thermal stress cycles are permissible at the stress levels anticipated. On this basis, it then appears desirable to concentrate on reducing pressure stresses rather than thermal stresses.

D. Core Composition and Configuration

The core composition and configuration designed to approach the conditions outlined above are presented in Fig. 2 and Table V. To achieve the desired linear heat fluxes, the uranium enrichment and subassembly positions were varied. A condition imposed on the obvious flexibility of enrichment was that the uranium enrichment be specified and held fixed for each specific technique of fuel fabrication. Thus, the $\mathrm{Cl}$ and.C3 pellets have the same enrichment, although the clad materials are different.

Several conditions were considered in the positioning of the subassemblies. Symmetry was maintained as closely as possible to simplify analysis and to subject the several elements of each type to similar power conditions throughout the experiment. 

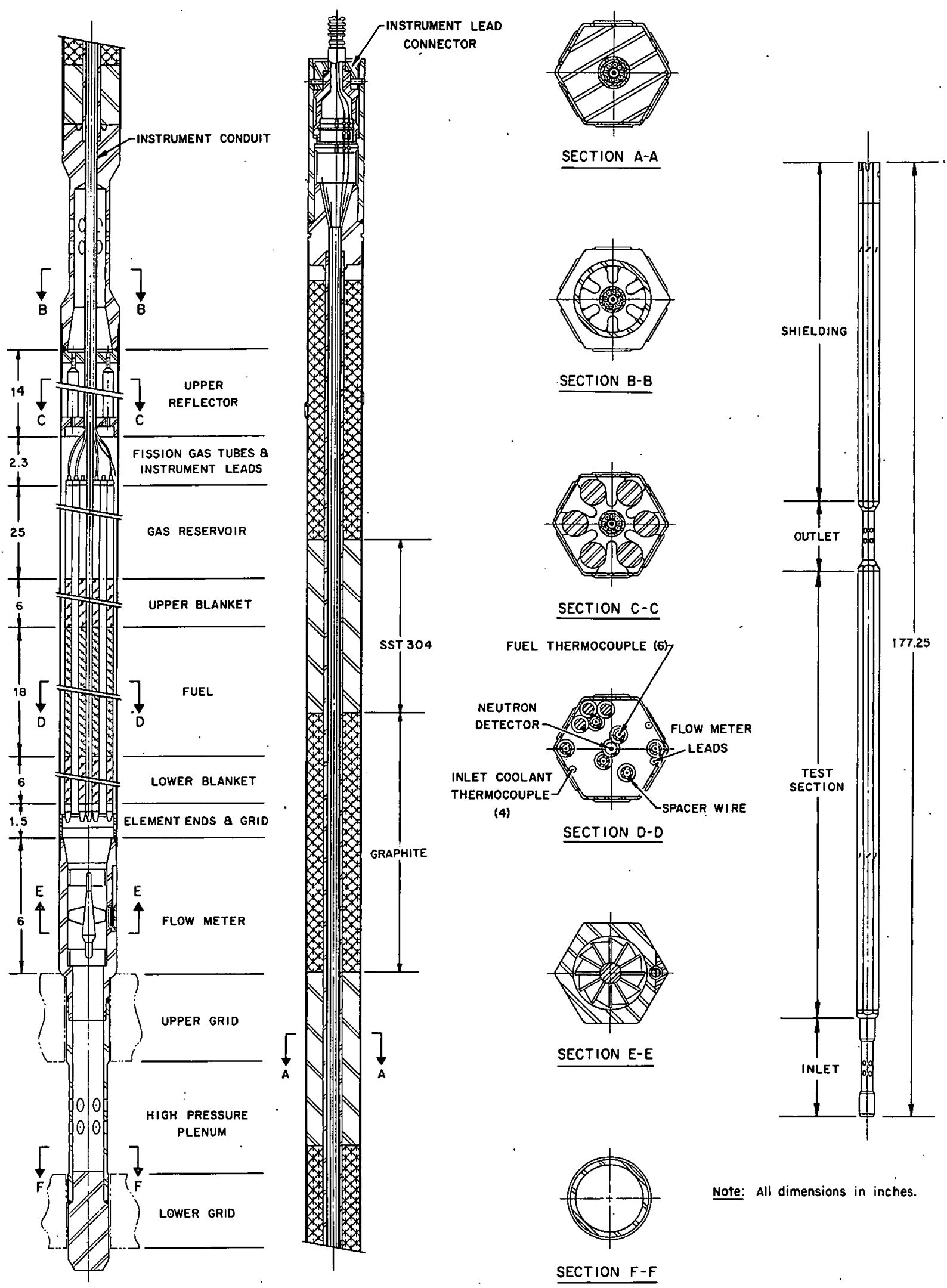

SECTION B-B

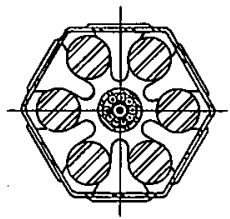

SECTION C-C

FUEL THERMOCOUPLE (6)
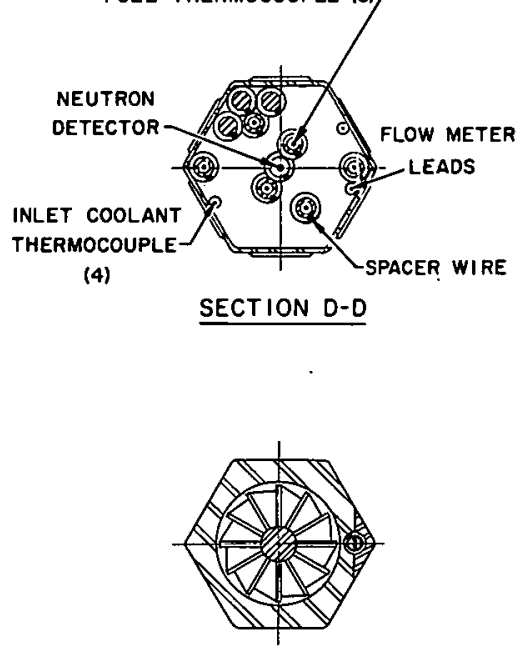

SECTION E-E

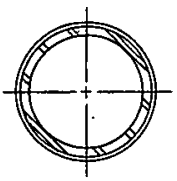

Note: All dimensions in inches.

Fig. 1. Instrumented Core Subassembly 


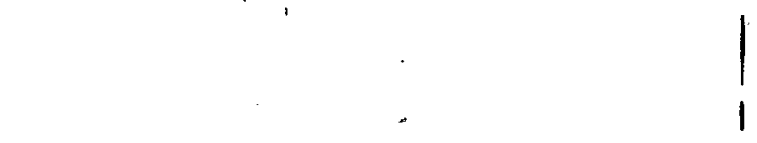

IRH IRRADIATION INTERVAL

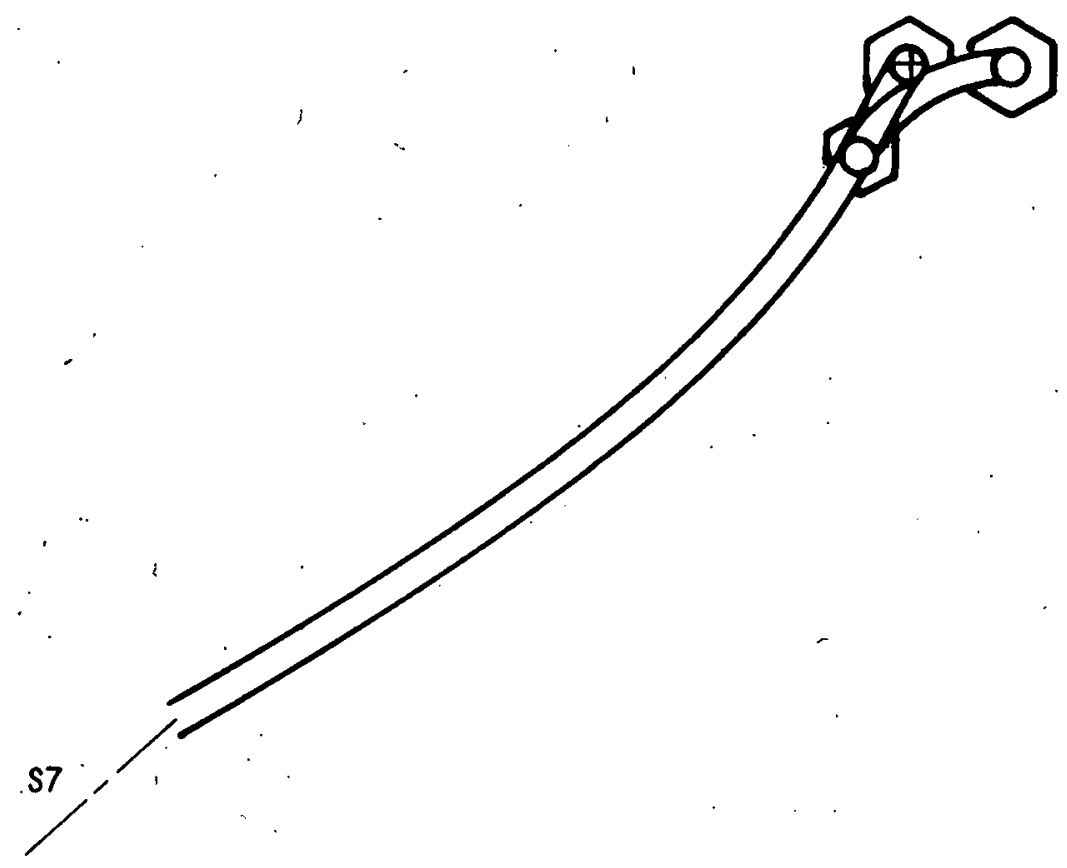




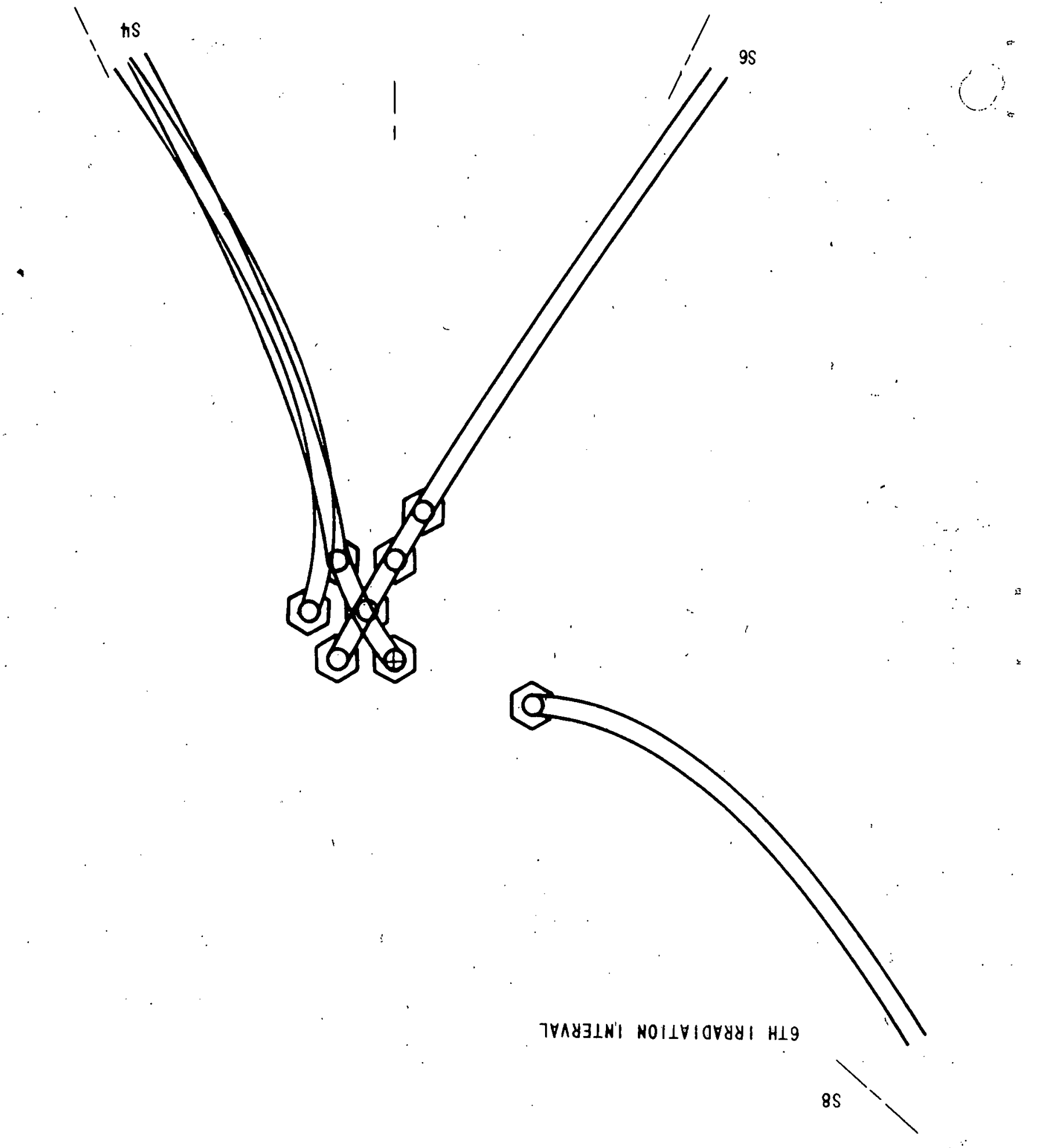


!<smiles>C=C1CC1=O</smiles>

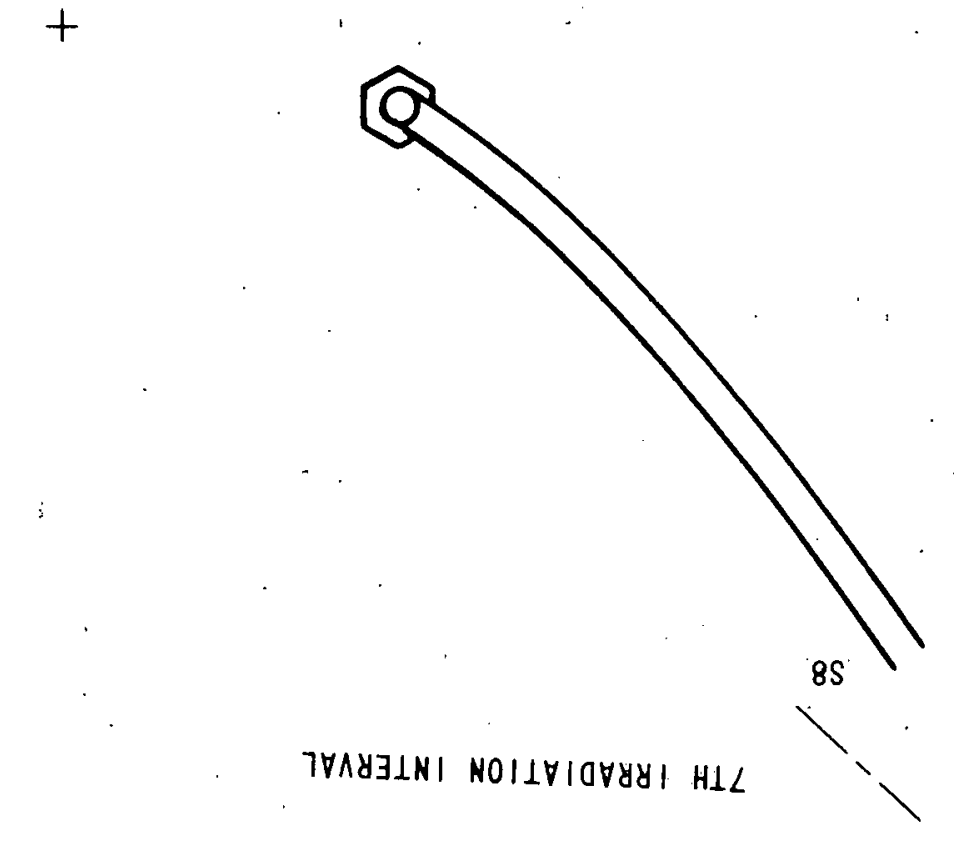

I 


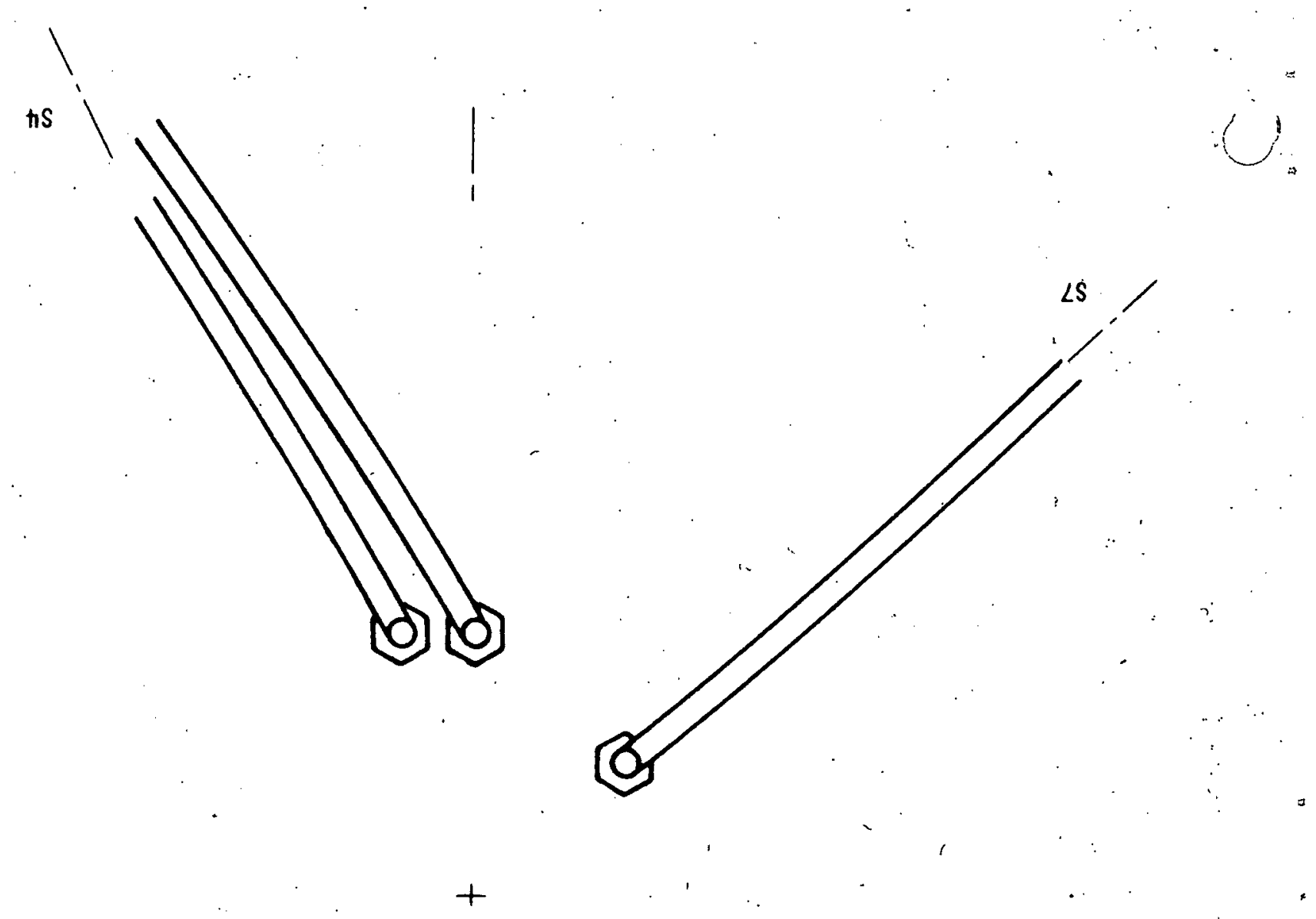

:

TYAYJLI NOLIVIOYYYI HLS

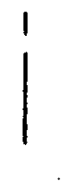




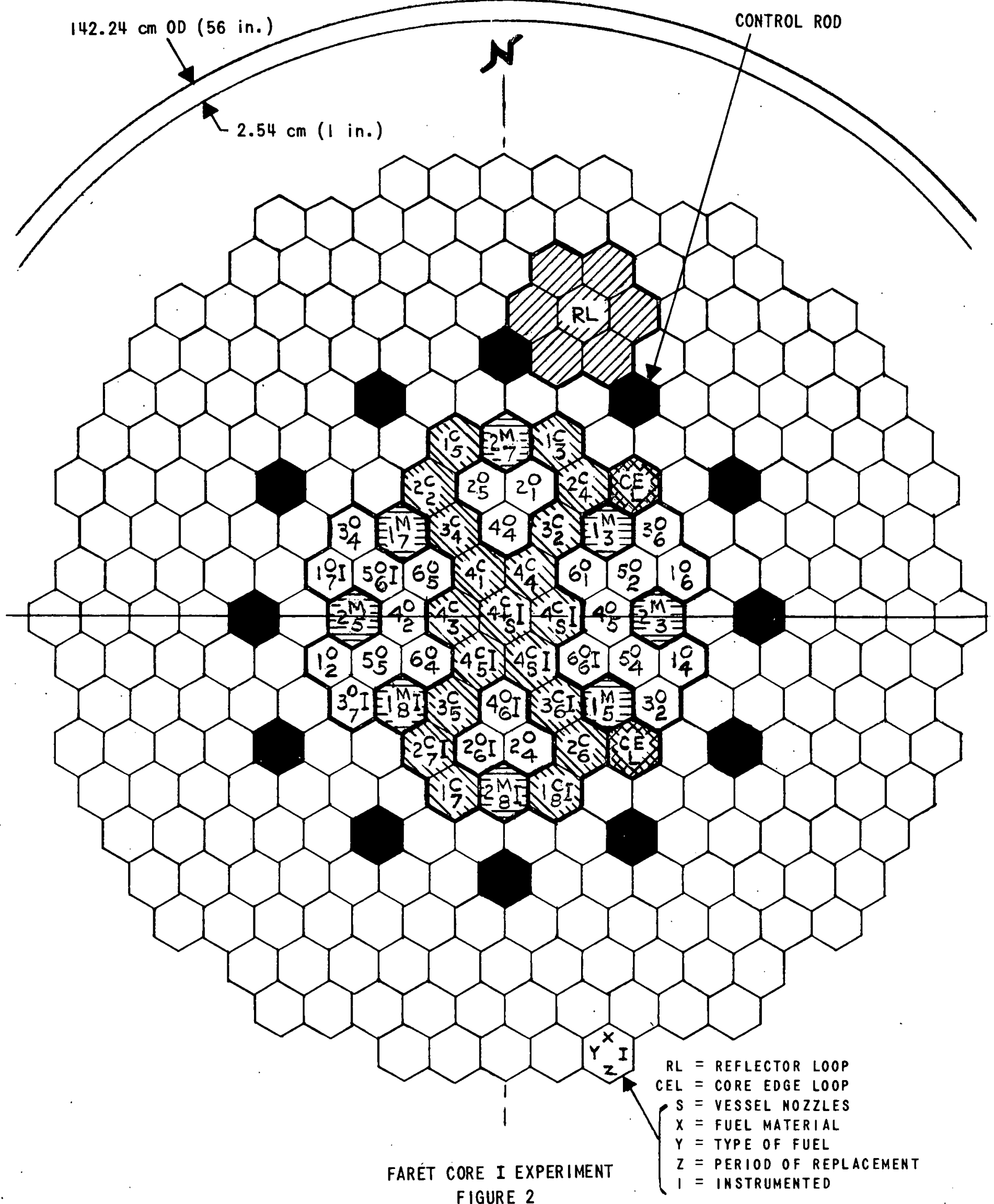




\begin{tabular}{|c|c|c|c|c|c|c|c|}
\hline \multirow[b]{2}{*}{$\begin{array}{l}\text { Row and } \\
\text { No. of } \\
\text { Subassembly }\end{array}$} & \multirow[b]{2}{*}{$\begin{array}{l}\text { Fuel } \\
\text { Type }\end{array}$} & \multicolumn{2}{|c|}{$\begin{array}{l}\text { Reactor Power: } \\
\text { Core Composition (v/o): } \\
\text { Core Volume: }\end{array}$} & \multicolumn{2}{|c|}{$\begin{array}{l}50 \text { Mw(t) } \\
\text { Ceramic Fuel } 37 / \text { Sodium 40/Structure } 22 \\
\text { U/Pu Atom Ratio } 6 / 1 \\
\text { Metallic Fuel } 30 / 5 \text { Sodium } 48 / \text { Structure } 22 \\
\text { U/Pu Atom Ratio } 5 / 1 \\
70 \text { liters; Height: } 45.7 \mathrm{~cm}(18 \text { in:) }\end{array}$} & \multirow[b]{2}{*}{$\begin{array}{l}\text { Avg. (Max) } \\
\text { Linear Power, } \\
\text { kW/ft }\end{array}$} & \multirow[b]{2}{*}{$\begin{array}{l}\text { \% Heavy } \\
\text { Atom Burnup } \\
\text { (180 days at } \\
\text { Full Power) }\end{array}$} \\
\hline & & $\begin{array}{l}\text { Approx. } \\
\text { U2035. } \\
\text { Enriched }\end{array}$ & $\begin{array}{l}\text { No. of } \\
\text { Elements per } \\
\text { Subassembly, } \\
\text { (diam, in.) }\end{array}$ & $\begin{array}{l}\text { Average } \\
\text { Power per } \\
\text { Subassembly, } \\
\text { MW }\end{array}$ & $\begin{array}{c}\text { Power } \\
\text { Density per } \\
\text { Subassembly, } \\
\text { MW/liter }\end{array}$ & & \\
\hline (1) 1 & $C 4$ & 0.67 & $37(0.29)$ & 1.5 & 1.1 & $27(31)$ & 5 \\
\hline (2) 6 & CA & 0.67 & 37 & 1.45 & 1.06 & $26(31)$ & 4.9 \\
\hline $\begin{array}{r}\text { (3) } 4 \\
4 \\
4\end{array}$ & $\begin{array}{l}04 \\
06 \\
\text { C3 }\end{array}$ & $\begin{array}{l}0.60 \\
0.60 \\
0.60\end{array}$ & $\begin{array}{l}37 \\
37 \\
37\end{array}$ & $\begin{array}{l}0.88 \\
0.88 \\
1.18\end{array}$ & $\begin{array}{l}0.64 \\
0.64 \\
0.88\end{array}$ & $\begin{array}{l}15(19) \\
15(20) \\
21(27)\end{array}$ & $\begin{array}{l}3.9 \\
3.9 \\
3.9\end{array}$ \\
\hline $\begin{aligned} & \text { (4) } 4 \\
& 4 \\
& 4 \\
& 4 \\
& 2\end{aligned}$ & $\begin{array}{l}02 \\
05 \\
C 2 \\
\text { M1 } \\
\text { M2 }\end{array}$ & $\begin{array}{l}0.65 \\
0.65 \\
0.67 \\
0.57 \\
0.57\end{array}$ & $\begin{array}{l}37 \\
37 \\
37 \\
61(0.22) \\
61\end{array}$ & $\begin{array}{l}0.84 \\
0.84 \\
1.01 \\
0.97 \\
1.0\end{array}$ & $\begin{array}{l}0.61 \\
0.61 \\
0.73 \\
0.71 \\
0.73\end{array}$ & $\begin{array}{l}15(20) \\
15(20) \\
18(23) \\
10(13) \\
10(13)\end{array}$ & $\begin{array}{l}3.6 \\
3.6 \\
3.6 \\
2.7 \\
3\end{array}$ \\
\hline $\begin{array}{r}\text { (5) } 4 \\
4 \\
4 \\
2\end{array}$ & $\begin{array}{l}01 \\
03 \\
C 1 \\
M 2\end{array}$ & $\begin{array}{l}0.65 \\
0.60 \\
0.60 \\
0.57\end{array}$ & $\begin{array}{l}37(0.29) \\
37 \\
37 \\
61(0.22)\end{array}$ & $\begin{array}{l}0.72 \\
0.69 \\
0.85 \\
0.84\end{array}$ & $\begin{array}{l}0.53 \\
0.50 \\
0.62 \\
0.61\end{array}$ & $\begin{array}{l}13(16) \\
12(15) \\
15(19) \\
9(12)\end{array}$ & $\begin{array}{l}3.3 \\
3.2 \\
2.7 \\
2.4\end{array}$ \\
\hline
\end{tabular}

The positioning was also influenced by the sequence of removal and replacement. Instrumented subassemblies are usually located so that the loading and unloading of other subassemblies are not made cumbersome by having instrumentation leads located over subassemblies to be removed. It is planned to remove the instrumented subassemblies in the latter.stages of burnup for each type element.

This makes possible the continuous recording of fuel and coolant temperatures, and possibly of coolant flow rates, neutron flux, and fissiongas release throughout most of the core life of each fuel-element design.

A preliminary placement of the instrumented subassemblies and the manner in which the cables may be laid out are shown in the overlays in Fig. 2. The sequence of removal coincides with the level of the overlays. When several assemblies are to be removed at the end of a period, the pattern will be to remove the innermost first and then continue radially outward.

If instrumented subassemblies cannot be placed adjacent to each other as shown in Fig. 2, an alternate arrangement will be made with at least one uninstrumented subas sembly separating each instrumented one.

Several alternate layouts are possible. For example, the C45I*, C35, and C27I subassemblies can be interchanged with the subassemblies C41, C34, and C22. As another example of this flexibility in the placement

*Carbide subassembly, Type No. 4, removal at end of fifth irradiation period, instrumented. 
of instrumented subassemblies, the $\mathrm{O} 37 \mathrm{I}$ and Ml8I assemblies can be interchanged with the $\mathrm{O} 34$ and $\mathrm{Ml} 7$ subassemblies, either separately or as a pair.

This flexibility will allow utilizing all the vessel penetrations (or nozzles) and will thus avoid congesting any single outlet. The penetrations S1, S2, and S3 are planned to be used exclusively for the core-edge loops and the reflector loop.

The overlays include several possible layouts for removal of the special C4S subassemblies. Optional instrumentation schemes for instrumenting the special subassemblies have been indicated, depending on the time of removal. Less leads are required than shown, as a consequence. The final arrangement of the instrumented subassemblies will depend on the capability of handling connectors, cables, and other related functions inside the reactor.

The advanced types of subassemblies referred to in Table II have not been specified. They are presently designated as C4S.

The radial power distribution within a subassembly varies about $10 \%$ from the average (see Fig. 3). With the axial maximum-to-average

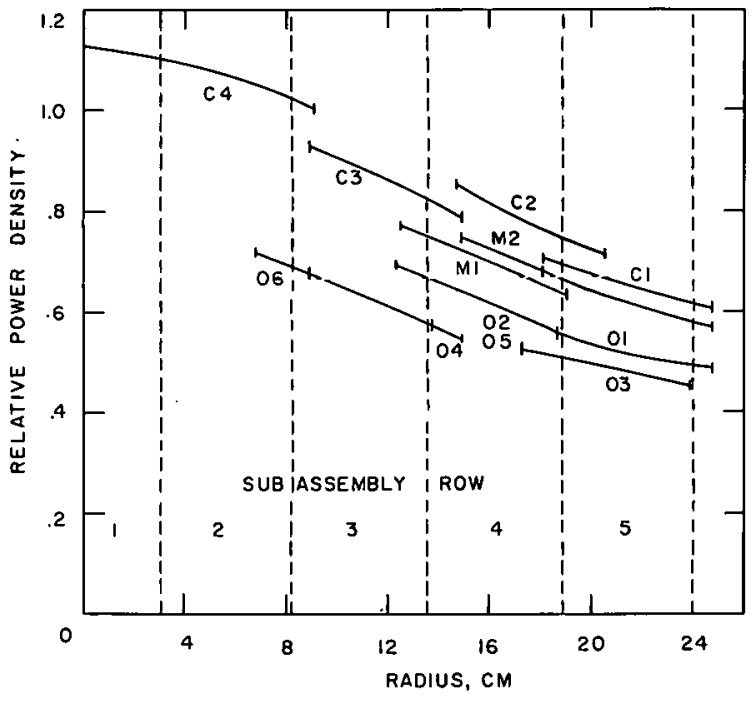

Fig. 3. Relative Radial Power Density Dis tribution at Core I Center Plane ratio of 1.16 , the overall maximumto-average power density is about 1.28. This factor was used in the approach to the design heat fluxes listed in Table III. The uranium enrichments also include the effect of control rods on the power-density distribution. Partially inserted control rods could reduce the average power distribution in the outer rows by $10 \%$. Therefore, the subassemblies in the outer row, when all factors are applied, approach the design heat flux.

The power density in the carbide subassembly $\mathrm{Cl}$ may be considered too high. If this is the case, the $\mathrm{Cl}$ elements may be moved into the "corner" positions of row 5. Two-

dimensional computations indicate that a $5 \%$ variation in the power densities can be expected between these two positions.

E. Considerations in Planning the Experimental Program

In planning the experimental program, an important factor in establishing the fuel removal and replacement sequence (see Table VI) was the 
total worth of the control system. The optimum experiment with respect to time, would be one in which the excess reactivity needed for the maximum per cent burnup is accommodated by the initial fuel enrichment. This would minimize the number of fueled assemblies required in the outer core region to maintain criticality. The addition of these assemblies reduces the overall power density and thereby lengthens the time to attain a given burnup. The approach to the optimum experiment is to design the control system with maximum reactivity worth.

TABLE VI. Calculated Nuclear and Control Parameters for FARET Core I Reference Design

Nuclear Data

Neutron Flux, $\mathrm{n} / \mathrm{cm}^{2}-\mathrm{sec}$

Radial Position

\begin{tabular}{|c|c|c|c|}
\hline \multirow[b]{2}{*}{ Energy Range } & & & \\
\hline & Core Center & Core Edge Loop & Reflector Loop \\
\hline$>1.35 \mathrm{MeV}$ & $0.8 \times 10^{15}$ & $0.3 \times 10^{15}$ & $0.3 \times 10^{14}$ \\
\hline $100 \mathrm{keV}-1.35 \mathrm{MeV}$ & $2.4 \times 10^{15}$ & $1.5 \times 10^{15}$ & $5.7 \times 10^{14}$ \\
\hline $1-100 \mathrm{keV}$ & $0.4 \times 10^{15}$ & $0.5 \times 10^{15}$ & $3.9 \times 10^{14}$ \\
\hline$<1 \mathrm{keV}$ & $6.5 \times 10^{11}$ & $1.8 \times 10^{13}$ & $1.2 \times 10^{14}$ \\
\hline Total & $3.6 \times 10^{15}$ & $2.3 \times 10^{15}$ & $1.1 \times 10^{15}$ \\
\hline \multirow{2}{*}{\multicolumn{3}{|c|}{$\begin{array}{l}\text { Prompt neutron lifetime, } \mu \mathrm{sec} \\
\text { Effective delayed neutron fraction, } \beta_{\text {eff }}\end{array}$}} & 0.21 \\
\hline & & & 0.0058 \\
\hline
\end{tabular}

Reactor Control Average Reactivity Coefficients, $\Delta \mathrm{k} / \Delta \mathrm{T}^{\circ} \mathrm{C}$

\section{Overall Doppler@ $750^{\circ} \mathrm{K} \quad$ Uranium \\ Plutonium}

Radial core expansion

Overall axial fuel expansion

Sodium expansion coefficient

Overall core region avg

Core and reflector

$-0.45 \times 10^{-6}$
$<+0.1 \times 10^{-6}$
$-10 \times 10^{-6}$
$-4 \quad \times 10^{-6}$
$-10 \quad \times 10^{-6}$
$-14 \quad \times 10^{-6}$

Estimated Range of Total Worth of Control Rods

Composition (v/o): $\mathrm{B}_{4} \mathrm{C} \mathrm{55/ \text {coolant } 2 5 / \text { structure } 2 0}$

No. of rods

$70 \% \mathrm{~B}^{10}$ enrichment

12

$0: 075-0.085$

$0.085-0.10$

Excess and Shutdown Reactivity

Heavy atom burnup

$0.035-0.060^{*}$

Operational temperature

Sodium $\Delta \mathrm{T}_{\mathrm{avg}}=500^{\circ} \mathrm{C}$ core and reflector $\quad 0.007$

Radial core expansion $\Delta \mathrm{T}_{\mathrm{avg}}=500^{\circ} \mathrm{C} \quad 0.005$

Axial fuel expansion $\Delta \mathrm{T}_{\text {avg }}=1500^{\circ} \mathrm{C}$ oxide $\Delta \mathrm{T}_{\mathrm{avg}}=1100^{\circ} \mathrm{C}$ carbide 0.004

$\Delta \mathrm{T}_{\mathrm{avg}}=500^{\circ} \mathrm{C}$ metal

Total operational temperature

Excess reactivity

Shutdown reactivity

Design worth of control system

0.016

$0.051-0.076$

0.020

$0.071-0.096$

*Depending on manner of compensating for burnup. 
Table VI. lists the calculated nuclear and control parameters for the reference core. Computations, along with related ZPR-3 critical experiments (see Section $F$ below) indicate that a $10 \%$ reactivity control system may be possible to attain, using 12 highly enriched boron-carbide rods. Also listed in Table VI are the reactivity effects due to the expansion of coolant and fuel system for the anticipated operating temperature changes. The total excess reactivity for the operational temperature change is estimated to be $1.6 \%$. Using a range of excess reactivity from 3.5 to $6.0 \%$ for burnup, along with a $2 \%$ shutdown margin and the $1.6 \%$ margin for the operational swing, the required range of control reactivity, 7.1 to $9.6 \%$, is within the estimated range of the total worth of the control rods.

F. FARET Critical Experiments

A series of FARET critical experiments was completed to confirm the physics analysis of multifueled, nonuniform core loadings. A primary interest was to establish experimentally the predicted control-rod reactivity worths of FARET core systems. Of equal importance was to substantiate the neutronic behavior of a mixed core when subassemblies of different type fuels are interchanged or replaced. Other measurements included the distributed worths of fuel and structural materials, reaction-rate traverses, and Rossi-alpha measurements.

\section{Control-rod Experimental Results}

The preliminary results of the experiments have been published in a series of ANL Reactor Development Program progress reports. ${ }^{6}$.Some analytical results for the reactivity worths of 12 control rods in the 84-liter mixed oxide core are compared with the experimental values in Table VII. The reactivity effects were studied for two $B^{10}$ enrichments of the boroncarbide control rods. The agreement between the computations and experiments establishes the range of control possible in the FARET reactor.

TABLE VII. Control-rod. Worths for

FARET Critical Experiments on Oxide Loading

\begin{tabular}{llllll}
\hline & \multicolumn{2}{c}{$30 \%$} & $\ddots$ & \multicolumn{2}{c}{$70 \%$} \\
\cline { 2 - 5 } $\mathrm{B}^{10}$ Enrichment & Inhours & $\Delta \mathrm{k}$ & & Inhours & $\Delta \mathrm{k}$ \\
\hline Experiment & -2544 & 0.051 & & -3897 & 0.077 \\
Calculation & -2450 & 0.049 & & -3800 & 0.076 \\
\hline
\end{tabular}

2. Establishing Concept of Mixed Core Systems

From Table VIII, the experimental data on the interchange of differently fueled assemblies in the oxide and carbide core loadings can 
be predicted to within $10 \%$. In the oxide core, the row indicated by $5 / 6$ means that the fueled assembly location was better represented by placing the assembly partly in the fifth and sixth. rows of the matrix in the critical facility.

TABLE VIII. Subassembly Replacements in the FARET Critical Experiment

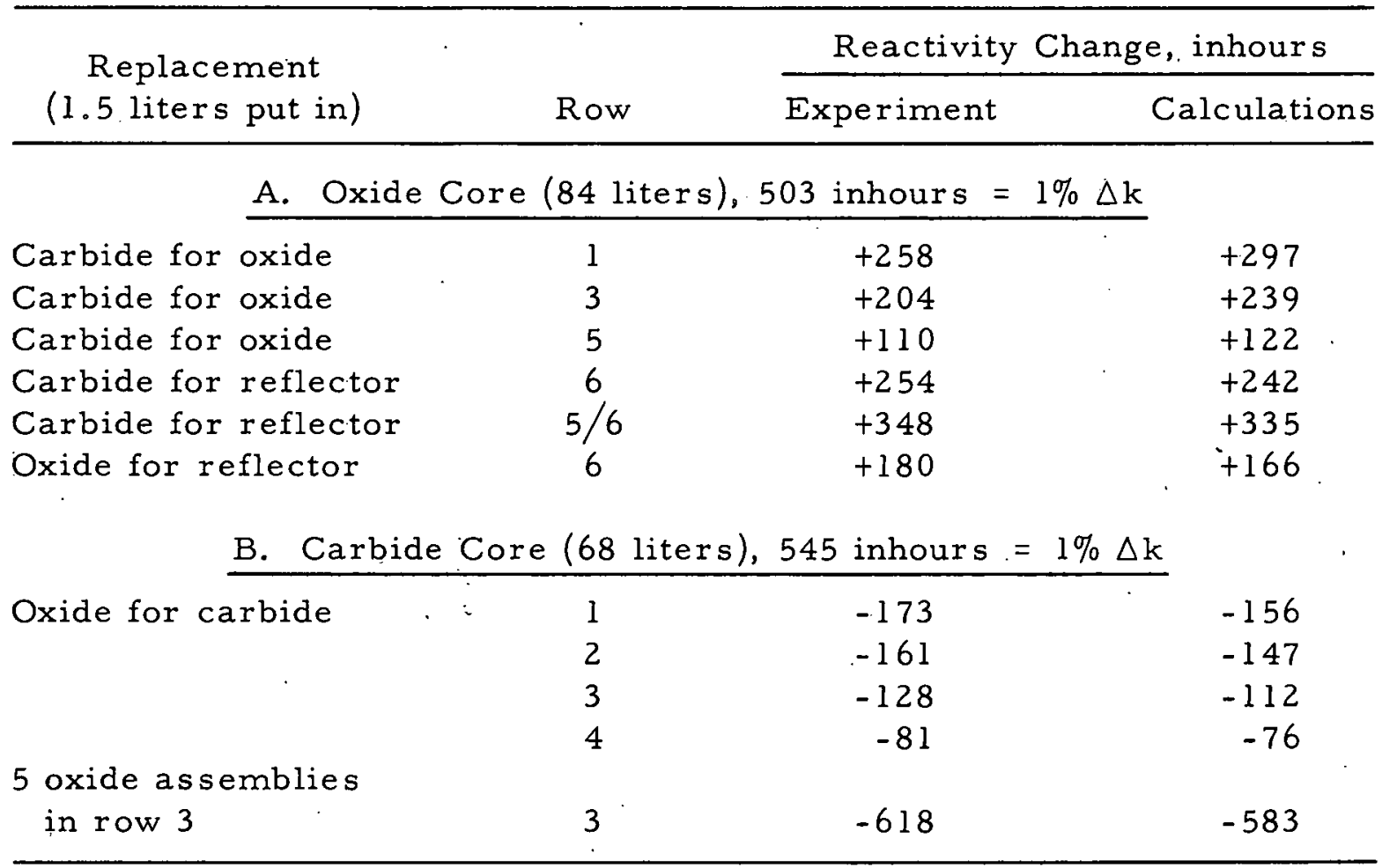

Pulsed neutron measurements made on the carbide and oxide core, were in reasonable agreement with the computed alpha (ratio of delayed-neutron fraction to neutron lifetime, $\beta / \ell$ ) value of $2.0 \times 10^{4}$ and $2.7 \times 10^{4} \mathrm{sec}^{-1}$ for the two cores, respectively.

The significance to be attached to the agreement between the experiment and the preliminary analysis, is that the behavior of a mixed core loading can be understood as well as that of a uniform core.

The maximum allowable excess reactivity for burnup studies in FARET Core I, will be determined from the critical experiments on the mockup of the core. The experiments have been planned to immediately follow the final fuel specifications.

G. The Experimental Program

The uranium enrichments quoted in this report include the $6 \%$ excess reactivity. If less than $10 \%$ total control worth is used, excess reactivity can 
be introduced by the addition of fueled assemblies at the edge of the core, either in the initial loading or after the first burnup interval.

The atom per cent burnup as a function of full-power operating days is presented in Table IX and in Fig. 4. The estimated atom per cent burnup as a function of time is plotted for the 12 types of fuel elements under study. The types of subassemblies to be removed after each irradiation period are indicated by circles in Fig. 4. There are only two metal M2 assemblies in row 4, so that after 9 a/o burnup, the burnup experiment for this type of fuel is to be followed with the M2 assemblies in row 5. After 780 days of fullpower operation, all but three types will have exceeded 14 a/o burnup (see Table IX). To expedite burnup of these types late in Core I life, the metal fuels $\mathrm{Ml}$ and $\mathrm{M} 2$ and the carbide fuel $\mathrm{Cl}$ could be moved to the third row enabling the additional 3 or $4 \mathrm{a} / \mathrm{o}$ burnup to be achieved during an additional period of 110 days. It is intended that the linear power in the se elements be maintained as close as possible to the initial power rating.

TABLE IX. Experimental Program Removal and Replacement Sequence

(Heavy Atom Burnup versus Days at Full Power)

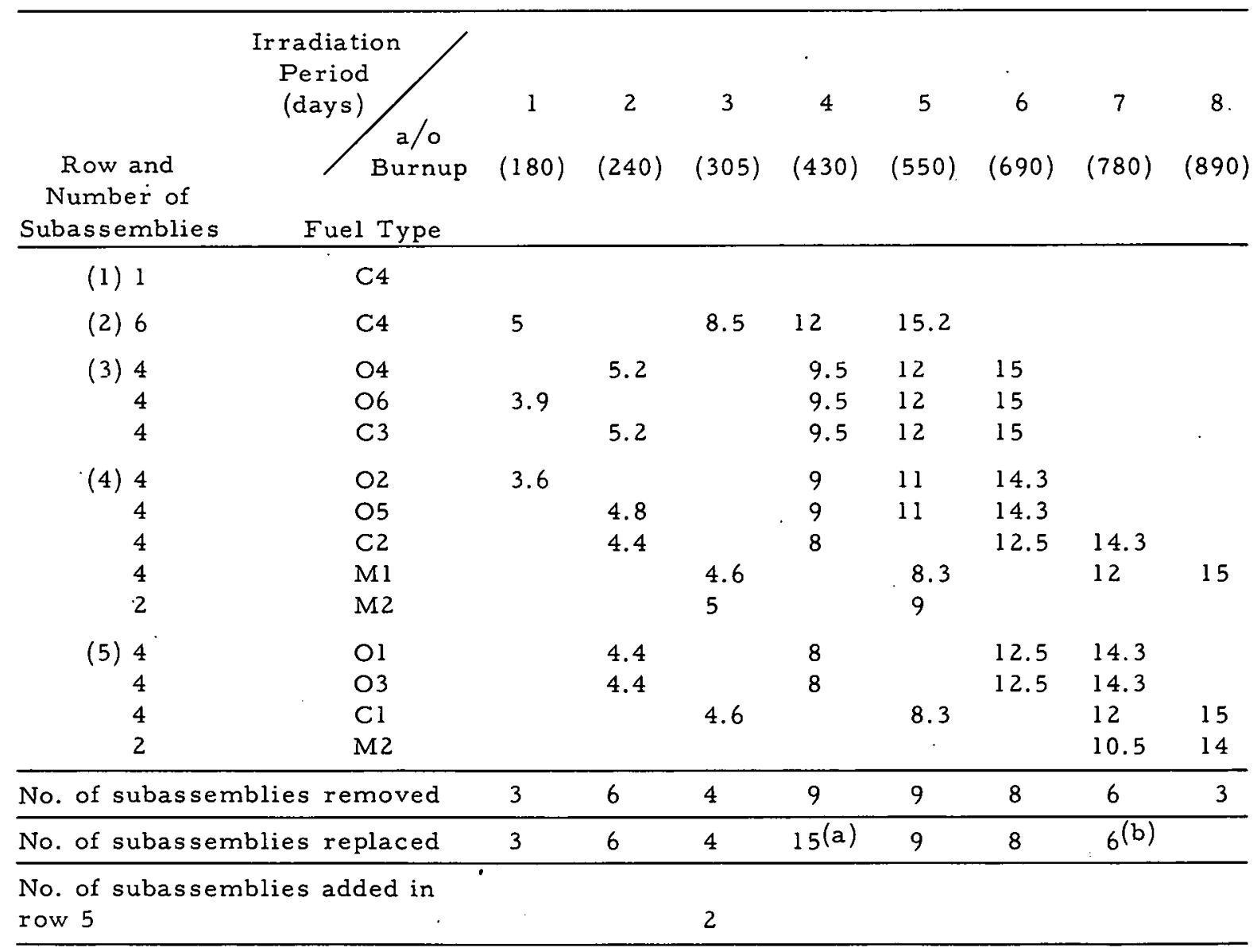

(a) Replace six C4 subassemblies or others as required to maintain desired reactivity for burnup beyond $10 \mathrm{a} / \mathrm{o}$.

(b) Irradiated subassemblies $\mathrm{Ml}, \mathrm{M} 2$, and $\mathrm{Cl}$ remaining may be moved into row 3 . 


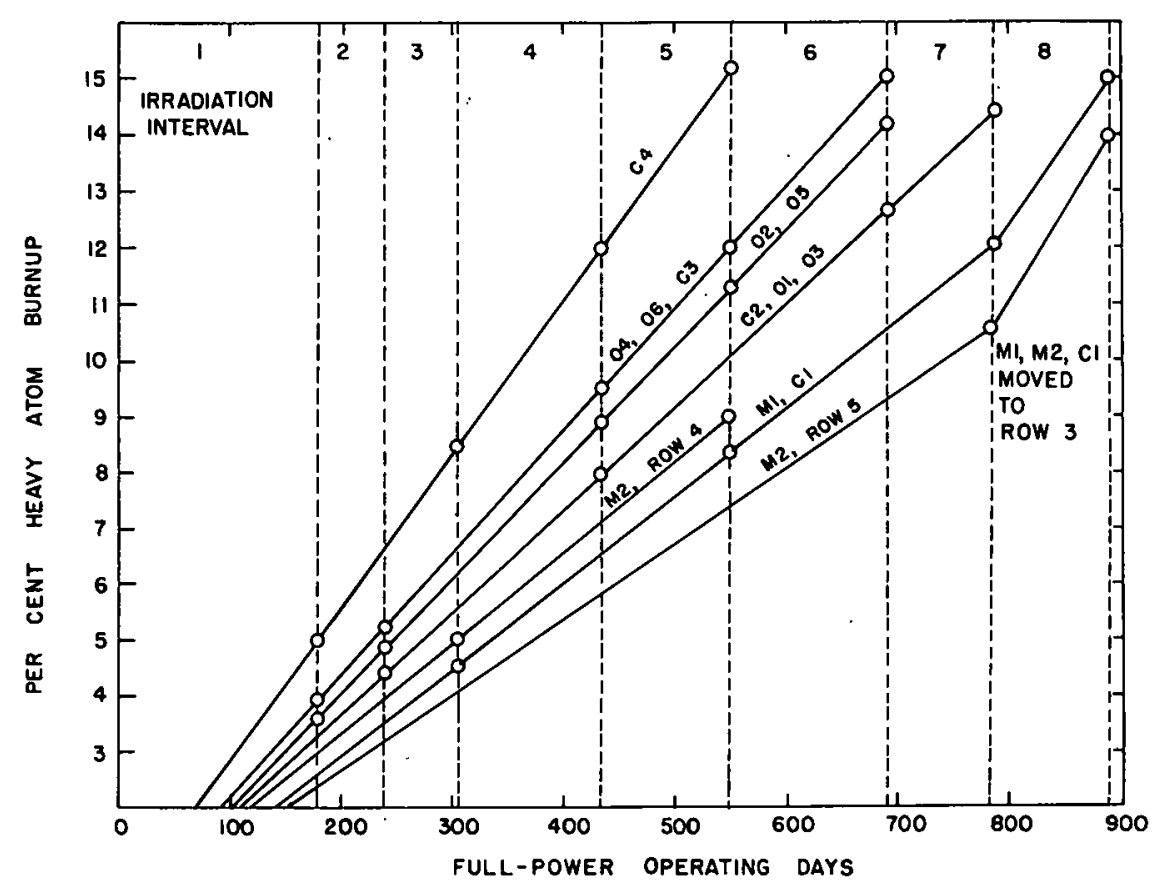

Fig. 4. Per Cent Heavy Atom Burnup versus Full-power Operating Days

The irradiation periods and the number of subassemblies removed and replaced are included in Table IX. The carbide C4 fuel assembly is expected to reach a $5 \mathrm{a} / 0$ burnup in 180 full-power operating days. At this time, two of the higher-performance oxide assemblies would also be removed for investigation. These two types of subassemblies would then be allowed to go directly to about 9 a/o burnup, should the investigation show satisfactory performance. An intermediate step, in which the other type oxides have burned to about $5 \mathrm{a} / \mathrm{o}$, would require some 60 additional days. As shown in Fig. 5, which shows $k_{\text {eff }}$ versus operating days, after the

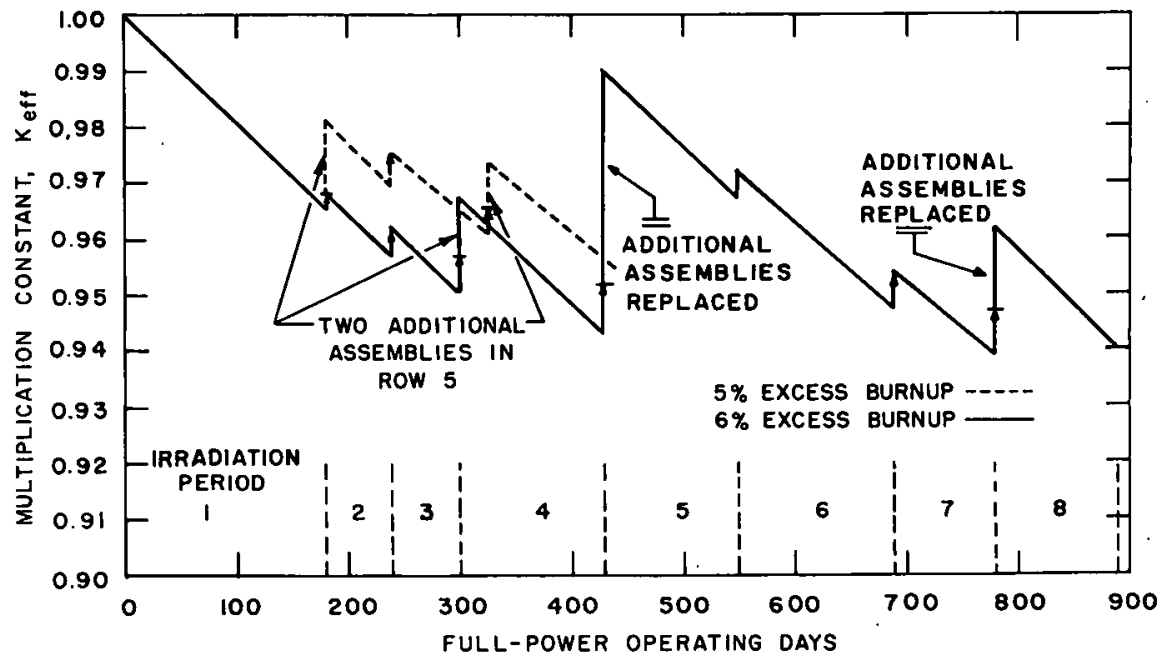

Fig. 5. Variation of Reactivity versus Fuel-irradiation Periods (Days) at Full Power 
third irradiation period (305.operating days), a reactivity loss of $5 \%$ is to be expected. If, at this time, two additional fuel assemblies are added in the fifth row (total worth of $1 \%$ ), the reactivity loss could be reduced to $3.2 \%$. The excess reactivity would now allow an additional irradiation period of 125 days, at the end of which most of the fuel types would have incurred between 8 and 12 a/o burnup. Included in Fig. 5 is an alternate plan which could be adopted for the case in which a $5 \%$ excess reactivity was allowed for the burnup experiment. The control system would have a total reactivity worth of $9 \%$. The only difference in the removal and replacement sequence is the addition of two fresh assemblies in the first replacement step. The burnup interval became somewhat longer so that the 8 to $12 \mathrm{a} / \mathrm{o}$ burnup occurs after 465 days.

At the end of a 430-day operating period at full power ( 1.5 years, assuming a plant factor of 0.75 ), the performance of close to 1000 fuel elements ( 22 subassemblies) would have been investigated at advanced thermal and burnup conditions. During this irradiation period, the fuel-pin cladding material would have been subjected to a total neutron exposure ranging from 0.9 to $1.4 \times 10^{23} \mathrm{nvt}$. The range of dosages resulting from neutrons above the $(n, p)$ and $(n, \alpha)$ threshold energies would have been as follows: 1.1 to $3 \times 10^{22} \mathrm{nvt}$ for energies above $1.35 \mathrm{MeV}$, and 2 to $4.6 \times 10^{22} \mathrm{nvt}$ for energies above $1 \mathrm{MeV}$. These threshold reactions may prove to be a main factor in limiting the life of the fuel cladding. In this case, then, the hard neutron spectrum in FARET would subject the clad material to a dose rate comparable to that attained in the softer spectrum of a large power reactor having a total flux of $1 \times 10^{16}$ neutrons $/ \mathrm{cm}^{2}-\mathrm{sec}$. For example, in some of the large power-reactor systems studied, the fraction of neutrons above the energy of $1.35 \mathrm{MeV}$ ranges from about 0.08 to 0.10 for ceramic and metalfueled elements, respectively. This should be compared with the fraction of 0.22 for the FARET core (see Table VI).

The performance limits of a fuel-element design, including the effect of radiation on the clad, as determined in the FARET experiment for a given fuel rating, are then directly applicable to a fuel-element design of a large power system.

To go to burnups of $15 \mathrm{a} / 0$, the necessary reactivity could be obtained by replacing some partly burned-up subassemblies with new subassemblies of the same design or of a new design. The choice could depend on the fact that the replacement is of a type that has shown a greater dimensional stability than the others or has had a better performance history. If needed, a few additional subassemblies could be added at the core edge. The sequence of removal and replacement of subassemblies could continue until all types, or all those that have performed satisfactorily throughout the course of the experiment, reach a burnup of 15 heavy a/o. 
The reactor downtime due to removal and replacement of the subassemblies will be maintained at a minimum, depending on the degree of confidence (obtained from previous research and development and from inspection of removed subassemblies) that the fuels will perform satisfactorily. The estimate of the time required for the usual loading and unloading operation is 2 weeks. Using an average plant factor of $7.5 \%$ over the duration of this experiment, the time to complete the program as outlined is expected to be 3 years. 


\section{ACKNOW LEDGMENTS}

The authors wish to acknowledge the following persons for the critical review of parts of the report, their helpful technical discussions, and their assistance in the computations.

Chemistry Division

M. S. Matheson

P. R. Fields

$\mathrm{J}$. R. Huizenga

$\mathrm{H} . \mathrm{H}$. Hyman

\section{Laboratory Director!s Office}

S. Lawroski

L. E. Link

D. Okrent

Metallurgy Division,

J. H. Kittel

L. Kelman

R. E. Macherey

A. D. Rossin

A. B. Shuck

S. J. Rothman

J. H. Handwerk

L. A. Neimark

Reactor Physics Division

R. Avery

D. A. Kucera

T. Abbott

M. Yokomi

H. H. Hummel

Chemical Engineering Division.

R.C. Vogel

M. Levenson

L. Burris

A. D. Tevebaugh

Idaho Division

J. K. Long F. W. Thalgott

A. L. Hess G. S. Brunson

R. E. Rice

Reactor Engineering Division
A. P. Grunwald
A. B. Smaardyk
L. J. Koch
S. B. Skladzien
W. R. Simmons

Solid State Science Division

P. H. Yuster

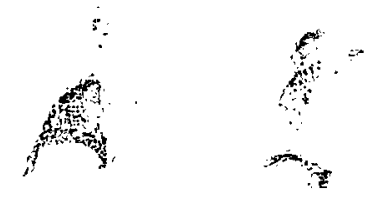




\section{REFERENCES}

1. W. R. Simmons, P. J. Persiani, and T. R. Bump, Fast Reactor Test Facility (FARET) Initial Experimental Program, Am. Nucl. Soc. Fast Reactor Technology, National Topical Meeting, Detroit, Michigan; April 26-28, 1965 ANS 100.

2. A. Smaardyk et al., Interium Report: FARET Experimental Program, ANL-6708 (April 1963).

3. N. L. Peterson, Isotope Effect in Self-Diffusion in Palladium, Phys. Rev. 136, p. A56 1964 .

4. E. K. Hyde, I. Perlman, G. T. Seaborg, The Nuclear Properties of the Heavy Elements, Prentice-Hall, Inc., New Jersey (1964), Vol. III, Chapt. 4.

5. L. Burris, Jr., I. G. Dillon, Estimation of Fission Product Spectra in Discharged Fuel from Fast Reactors, Nucl. Sci. Eng. 2, No. 5 (Sept 1957), pp. 567-581. See also ANL-5742 (Dec 1957).

6. Argonne National Laboratory Reactor Development Program Progress Reports; ANL-7017, Feb 1965; ANL-7028, March 1965; ANL-7045, April 1965; ANL-7046, May 1965; ANL-7071, June 1965; ANL-7082, July 1965; ANL-7090, Aug 1965. 